Article

\title{
Where the Heroes and Sky-Goers Gather: A Study of the Saurata Pilgrimage
}

\author{
Paul B. Donnelly \\ Department of Comparative Cultural Studies, Northern Arizona University, Box 6031, Flagstaff, AZ 86011, USA; \\ Paul.Donnelly@nau.edu
}

Received: 3 July 2017; Accepted: 16 August 2017; Published: 21 August 2017

\begin{abstract}
Tibetan and Himālayan Buddhist doctrine and meditative traditions have been extensively studied and are well-known even to non-scholars, but pilgrimage and other non-elite practices have received far less attention. Pilgrimage is one of the most important practices for Tibetan and Himālayan Buddhists, whether traditional scholars, ordinary monks, lay yogis, or Buddhist laypeople. Scholarship on pilgrimage has increased significantly since the 1990s, and has tended to focus on territories within the political boundaries of the Tibetan provinces of the People's Republic of China. This study looks at a pilgrimage in what was once the far western end of the Tibetan empire, but is now within the political boundaries of India. Being outside of the People's Republic of China, this pilgrimage escaped the disruption of such practices that occurred within the PRC during the Cultural Revolution and after. Having interviewed people in the region, and performed the pilgrimage myself, this study shows that this pilgrimage possesses features common to Tibetan pilgrimage to sites of tantric power, but also has its own unique qualities. This study provides new data that contributes to the growing body of knowledge of Tibetan pilgrimage and to our understanding of such practices among the Buddhists of Himālayan India.
\end{abstract}

Keywords: pilgrimage; Tibetan Buddhism; Himālayan Buddhism; tantra

\section{Introduction}

In the opening of his book Pilgrimage in Tibet, Alex McKay (McKay 1998, p. 1) asserts that pilgrimage is a core element of religious practice in the Himālayan cultural world. McKay concludes, that "through an examination of pilgrimage in Tibet we can, therefore, gain great insight into a wide variety of aspects of Tibetan history, culture, and identity, as well as illuminating wider fields and disciplines of study." The doctrinal and meditative traditions of Himālayan Buddhism have been available for study in the west largely through the cooperation of the monastic and scholarly elite members of these traditions. Information about the popular practices that constitute the religious lives of most Himālayan people, whether monastic or lay, has been far less available or sought. Such practices, and the underlying worldview, are found throughout the Himālayan regions and form the basis of a unifying culture across them, with pilgrimage being one of the most central and pervasive.

The scholarly study of Tibetan pilgrimage is a relatively new field of inquiry. A few scholars such as Guiseppe Tucci (e.g., Tucci 1988) and Robert Ekvall (e.g., Ekvall and Downs 1987), were working before the Chinese takeover of Tibet, but after 1959 scholarly access to Tibetan pilgrimage practices was severely restricted. Beginning in the mid-1980s, the PRC began to relax restrictions on Tibetan religious practices, and scholars were able to observe pilgrimages, though the question of how restricted or transformed these practices were since the pre-Chinese period now needed to be taken into consideration. The mid to late 1990s were a landmark period for scholarship on Tibetan pilgrimage. In 1994-1995 Tibet Journal published four special editions on sacred space in Tibetan cultural regions. The articles were subsequently published in 1999 as, Sacred Spaces and Powerful Places in Tibetan Culture: 
A Collection of Essays (Huber 1999a). Mandala and Landscape (Ramble 2007a), building on the foundation established by Tucci's Theory and Practice of Mandala (Tucci 1971), contains a wide-ranging set of articles concentrating on Tibet, but also includes articles on India, China and Japan. The same year, another important volume, Pilgrimage in Tibet (McKay 1998), collected papers presented at the 1996 conference of the Institute for Asian Studies in Leiden. In 1999, Toni Huber published the first book-length study of a Tibetan pilgrimage, the Tsari pilgrimage in southeast Tibet (Huber 1999b). ${ }^{1}$

Himālayan people living outside the borders of Tibet have the same reverence for pilgrimage, and in these regions they have not encountered the disruptions to religious observances as Tibetans have since the occupation and repression by the government of the People's Republic of China. Compared to studies of Tibetan pilgrimage within the modern political boundaries of the People's Republic of China, pilgrimages in culturally Tibetan areas of India and other Himālayan countries (Bhutan, Nepal and Sikkim) have received relatively little attention. The pilgrimage under consideration here is located on the Indian side of the Indo-Chinese border, so its study offers a glimpse into the practice of Tibetan pilgrimage that has not been interrupted by outside forces and provides a case study of pilgrimage in western Tibet that will contribute to the broader knowledge of the practice of pilgrimage across the Tibetan cultural areas. Having talked to people in Nako village over the past decade, performed the pilgrimage with two well-informed pilgrims, ${ }^{2}$ and read and translated the pilgrimage guidebook (gnas yig) (see Appendix A), it will be shown that this Himālayan Buddhist pilgrimage is consistent with many of the features of other Tibetan pilgrimages, but that there are some unique characteristics as well.

\section{Pilgrimage in the Tibetan Cultural Regions}

Like its usage in other religions, "pilgrimage" in Tibet refers to a journey to a place that is regarded as sacred. In the Tibetan language, the terms used for this ritual journey are nékor (gnas skor) or néjel (gnas mjal), meaning to go around (skor) or encounter/meet (mjal) a né or sacred place (gnas). Circumambulation as a religious practice can of course be traced to earlier Indian Buddhist practices directed toward stupas and other relics of the Buddha. Né means simply "place" but the term carries the implicit meaning of being a place where sacred power dwells. ${ }^{3}$ The sacredness of a né may arise from a number of different sources, including that of autochthonous deities of place, the physical hierophany of high tantric deities, the residual power of a great ancient Buddhist master, or even a living Buddhist master. A né may also be understood differently across time, or between different groups, e.g., between Buddhists and Bön-pos.

The sources of this power can be understood in a number of ways, which may overlap. Most broadly, scholars have repeatedly observed that Tibetans understand the natural world as teeming with powers, both benign and hostile, with which humans have to interact in myriad ways. From subterranean water spirits $(k l u)$, to local terrestrial spirits (sa bdag, gzhi bdag), to mountains identified with territorial gods (yul lha), the Tibetan landscape is alive with awesome presences, with which humans must cohabit, to their benefit or peril. Territorial gods and their mountains are important recipients of pilgrimage, either being identified with a high Buddhist deity or simply continuing to exist as the territorial god alongside the later Buddhist understanding of the site. Spirits of this sort are

1 For a comprehensive bibliography on Tibetan pilgrimage, see Buffetrille's entry on Oxford Bibliographies online (Buffetrille 2013).

2 I have visited Nako village yearly since 1996 as part of a study abroad trip that I lead to Himachal Pradesh. My interest in and knowledge of the Saurața pilgrimage slowly grew over this period. When I was eligible for sabbatical, this project was my first choice for further study. My principal informants were Mrs. Chimed Dolma; Mr. Arjun Negi; Mr. Chewang Dorjé Negi, President of the Hangrang Buddhist Association; Mr. Shanta Kumar Negi, former Head of the Nako Youth Club; and Lama Ngawang Negi, a village authority on the pilgrimage, and the transcriber of the pilgrimage guide. The latter two were my guides for the pilgrimage that I did on 12-13 September 2014.

3 For a discussion of this term and its implications, see "Putting the Gnas Back into Gnas-skor: Rethinking Tibetan Pilgrimage Practice", in (Huber 1999a, pp. 79-80). 
sensitive to impurity or insult, and may inflict harm upon the offender. More dangerous are numerous classes of demons, male and female, who are also quick to harm and are by nature malevolent.

Above these local spiritual presences are indigenous Tibetan deities who were subdued by the legendary tantric Buddhist master Padmasambhava or Guru Rinpoché, in the 8th century. At first inimical to the new religion, these warrior gods, mostly of a class of deity known as the "haughty ones" (dregs pa), were tamed by Padmasambhava and bound by oaths to protect Buddhism. These gods were integrated into the Tibetan Buddhist pantheon as dharma protectors. While serving the cause of religion, these gods remain worldly protectors ('jig rten pa' $i$ srung ma), i.e., they are not awakened, and so must be approached with caution and respect, constantly being reminded of their vows to protect Buddhism. Another class, the supermundane protectors ('jig rten las 'das pa' $i$ srung ma), are understood to be above samsaric limitations and concerns, and are often said to be manifestations of Buddhas or Bodhisattvas. In some cases, these higher protectors are regarded as tantric meditational deities, or yidam (yi dam), worthy of being objects of refuge, and more likely to be the source of power of a né.

These deities were brought to Tibet from India as Buddhism was propagated in Tibet in the 8th century and then again in the 11th century. Vajrayāna meditative praxis centers on the visualization of tantric deities with their retinues in their mandala palaces. The imposition of this Vajrayāna conception transformed indigenous nés along Buddhist lines in a process that has been called the "mandalisation" of Tibetan sacred sites, and is part of a broader "Buddhacisation" of Tibetan religion. While these processes largely overwrote indigenous or Bön narratives of sacred sites, the process was not complete in all cases, with some sites being understood as Buddhist, Bön, or folk religion. ${ }^{4}$

The foremost deity and mandala that was imposed on Tibetan sacred sites was Denchok Khorlo Dompa (bde mchog 'khor lo sdom pa, Sanskrit: Cakrasamvara), hereafter referred to as Khorlo Dompa. ${ }^{5}$ Khorlo Dompa is central to the practice of the Sakya (sa skya), Kagyü (bka' brgyud), and Geluk (dge lugs) sects, and it is particularly important to the Drukpa ('brug pa) subsect of the Kagyü, which was instrumental in establishing some of the major pilgrimage sites and routes, including the pilgrimage discussed here. The Khorlo Dompa Tantra is a yoginī tantra, a class of tantric text/teaching that emphasizes goddesses and transgressive sexual and mortuary imagery. In the mandala, the central deity couple, Khorlo Dompa and Dorjé Pakmo (rdo rje phag mo, Sanskri: Vajravārāh $\bar{\imath}$ ), ecstatically dancing in sexual union in their palace, fanged, and bedecked in skulls, are surrounded by wrathful goddesses called khandromas, or "sky-goers." (mkha' 'gro ma, Sanskrit: d̦ākinī). The presence of the khandromas figures prominently at numerous nés, protecting the sites, and if appeased, bestowing blessings and empowerments.

Another important aspect of this tantra is its mapping of twenty-four pilgrimage sites (pitha-s), corresponding to the parts of the deity's adamantine body or that of the tantric yogi, onto the Indian subcontinent. The concept of a network of pịthas first arose in Śaiva and Śākta circles-where the sites were places empowered by the presence of Śakti and Śiva, and were destinations for pilgrims and yogis. This idea and some of the very same sites were then imported into Vajrayāna Buddhism. The Sanskrit term pițha was translated into Tibetan as né, homologizing the indigenous concept with the new Vajrayāna one. These sites would be remapped onto the Tibetan landscape, subjugating and sacralizing the Land of Snows with the power and authority of the Khorlo Dompa tantra, its practices, and its advanced practitioners.

A useful indigenous concept for the understanding of the power of a né, and its transformative effect on the pilgrim is that of jinlap (byin rlabs) often translated as "blessing," though here perhaps

4 See Katia Buffetrille, "Reflections on Pilgrimages to Sacred Mountains, Lakes and Caves", in Pilgrimage in Tibet, in (McKay 1998, pp. 18-34). For a discussion of the contested status of Tisé between Bönpos and Buddhists, see Charles Ramble, "The Politics of Sacred Space in Bon and Tibetan Popular Tradition," in (Huber 1999a, pp. 3-33).

5 The Tibetan translation of the Sanskrit includes two different readings of the name Cakrasamvara. Though it is common in Tibetan Buddhist scholarship to privilege Sanskrit, we will prefer Tibetan names and terms. For a discussion of the complexities of this name, see David Gray's discussion (Gray 2007, pp. 35-37). 
"empowerment" is a better term. The early Tibetan kings were said to possess jin, "splendor" or "glory," which flooded the landscape, the state, and its inhabitants. In Buddhism, the concept developed early that the charisma and power of the Buddha was transformative. After his death, his mortal remains, regarded as powerful relics, were interred in large reliquaries (stüpa), which became pilgrimage sites at the major places associated with his life. The relics of other great masters came to possess a similar power, and the stüpas housing them were venerated across the Buddhist world. In the Vajrayāna context, the power of Khorlo Dompa and his mandala subdue the spot as a Buddhist site and empower the environment and pilgrims who come there.

\section{Benefits of Performing the Pilgrimage}

What one gains from the performance of pilgrimage depends on the relative spiritual status of the pilgrim. Pilgrimage is a much more common practice than the sophisticated Vajrayāna forms of meditation practiced by the religious elite, but it would be a mistake to equate pilgrimage exclusively with ordinary practitioners. Pilgrimage guidebooks often describe these two categories of people as "ordinary people" (so skye bo) and "excellent" or "holy people" (skye bo dam pa). It is important to note here that the different experiences to be had by the relatively more or less advanced practitioners does not necessarily correlate to a difference between monks and lay people. Throughout the Tibetan literature about pilgrimage, it is assumed that advanced yogis have much to gain from travelling to a né and that their experience of them will be more profound than those of the uncultivated lay person or monk. Tibetan conceptions of the pithas of the Khorlo Dompa corpus always allowed for an interiorized understanding, with the pithas being present in the body of the yogi. The yogi could "visit" these sites in his or her own body, rendering the travel to the actual places (whether understood to be in India or elsewhere) unnecessary. Nonetheless, yogis have always visited such sites. Their presence at them aided their progress in advanced meditation, and for the greatest of them, their realizations contributed to the power of the place. The power of Khorlo Dompa mandala, the charismatic power of realized masters and the presence of the khandromas all contribute to the yogi's accelerated progress along the path to realization.

For the less-advanced lay person or monk, the benefits sought from visiting a né tend to be more mundane. Despite the orthodox Buddhist discourse of karma as exclusively determining one's good or bad fortunes, the indigenous Tibetan conceptions of evil (sdig pa) and pollution (grib) are often employed when discussing the benefits of pilgrimage. Evil here refers to the results of moral transgressions, while pollution refers to an embodied negativity that results from angering various kinds of supernatural beings, including transgression of social norms or bodily substances. Many kinds of ritual action can mitigate or remove evil and pollution, but pilgrimage is said to specifically do so by the often-arduous physical work of the pilgrim's body and by the general transformative effect of contact with the empowered landscape and its empowered substances, such as soil, rocks, plants, and water. ${ }^{6}$

\section{Location of the Research}

The pilgrimage discussed here is in the Hangrang region of the Kinnaur district in the Indian state of Himachal Pradesh (Figure 1). The Hangrang region comprises the Kinnaur district's portion of the Spiti valley. Hangrang contains only eight villages at different elevations above the Spiti river. Moving north and west along NH 22, the Spiti river intersects the Sutluj coming in from Tibet to the East at Khab. At Khab bridge, the river is at an altitude of approximately 8800 feet. From here the road cuts through a deep canyon before moving up, via switchbacks to a higher plane along the river. From the main road, Nako is accessed via a seven-kilometer spur of the road that leads up to the village and its sister village, Maling. Nako sits at just under 12,000 feet and is the highest village in Hangrang.

6 See Huber's discussion (Huber 1999b, pp. 14-20) of the general benefits of pilgrimage. 
Hangrang, Lahaul and Spiti were closed to tourism from 1947 until 1992, and foreign visitors still must obtain a permit to visit, with limits on how long one can stay in the region.

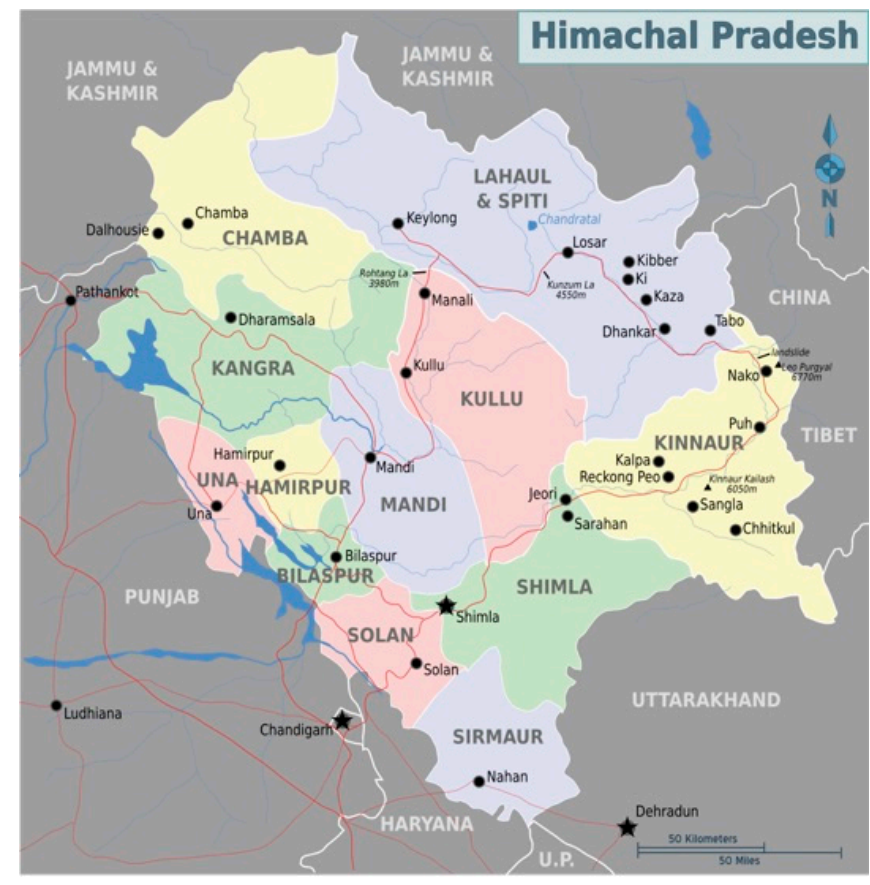

Figure 1. Map of Himachal Pradesh and surrounding areas.

Along with Lahaul and Spiti, the neighboring regions to the north and west, Hangrang played an important part in the 2nd propagation of Buddhism into Tibet from India. ${ }^{7}$ Though Buddhism had been established in Tibet in the eighth century, at the instigation of the early Tibetan kings and in association with the scholar-monk Śantarakșita and the siddha Padmasambhava, it was regarded by the pious king of the western Tibetan kingdom of Gugé, Yeshé Ö (ye shes od, 959-1036), as having become corrupt and in need of reform. The King invited the temple-builder and translator Rinchen Zangpo (rin chen bzangs po, 958-1055) to Tibet to purify Buddhism by establishing a translation academy to translate texts from Sanskrit in Tibetan to serve as the basis of an orthodoxy and by re-establishing monastic Buddhism in Tibet.

The monastic complex in Nako is locally considered to be one of the 108 monasteries founded by Rinchen Zangpo, though modern scholarship attributes the compound to shortly after the death of Rinchen Zangpo, ${ }^{8}$ and it is one of the major features of the village's religious identity and practice.

This monastic complex has received a significant amount of art historical attention, and a multi-year preservation/restoration project based at the University of Vienna. The Nako Preservation Project website is an invaluable resource on the Nako monastic complex. ${ }^{9}$ There has been relatively little attention on the village's other sites, or the religious lives of its inhabitants. The published records of Tucci's expeditions to the area between 1933 and 1939 (Tucci 1988) are significant sources of knowledge about Nako, but here again the emphasis was on the monuments rather than what people in Nako had to say about their own religious lives or any documentation of what people were doing. The monastic complex is now more museum than monastery. I was told that this was at least partially

7 Though as Davidson (Davidson 2003) has pointed out, the emphasis on the western re-introduction, at least partially a product of Geluk concern to link itself and its purity to that of the Kadam, tend to downplay the equally crucial reestablishment that came from the monks returned from the east.

8 See, for example, Laxman S. Thakur (Thakur 1996).

9 http://www.univie.ac.at/fsp-programm/wmf/ (Klimburg-Salter 2002). 
because of people stealing the bits of gold from the paintings over the years had caused the village to guard the structures more carefully. Currently, two young monks from the Drukpa monastery at Bhuntar are posted at the ancient monastery. I was told by one of them that he and the other monk had just arrived recently and would have to stay for a year, after which time someone new would be sent. The young monk's knowledge of the images and paintings in the complex was rudimentary, which is not terribly surprising, but more interestingly, he either did not know, or did not like the idea, that one of the four buildings was the shrine to the mountain deity Riwo Purgyel. ${ }^{10}$ There is a shrine dedicated to the Dharma Protectors, but daily rituals are done in the old assembly hall on a daily basis, and the space was still used from time to time for special occasions. A new assembly hall stands nearby, as does the residence constructed for the Dalai Lama, both of which were consecrated by the Dalai Lama in 2006. The residence is only used for the Dalai Lama, though the other quarters belong to Lochen Rinpoche, who lives in the region and is the current incarnation of Rinchen Zangpo. The sectarian affiliation of the pilgrimage, consistent with much of the region, is with the Drukpa sect.11

\section{The Druk Lineage and the Opening of the Saurata Né}

The Druk ('brug) lineage is one of the sub-sects of the Marpa Kagyu (mar pa bka' 'gyur). It was established by Tsangpa Gyaré Yeshé Dorjé (gtsang pa rgya ras ye shes rdo rje, 1161-1211), who was one of the disciples of Pakmodrupa Dorjé Gyelpo (phag mo gru pa rdo rje rgyal po, 1110-1170). The name Drukpa ('brug pa) came from a vision had by Tsangpa Gyaré in which he saw nine dragons ('drug) fly up from the earth into the sky when he was on pilgrimage. Tsangpa Gyaré's lineage flows down from the great systematizer of Kagyu, Gampopa Sonam Rinchen (sgam po pa bsod nam rin chen, 1070-1153), who united the more ecstatic siddha lineage that he received from Tibet's great yogi Milarepa (mi la ras pa, 1040-1123) with that of the monastic Kadam tradition. However, Tsangpa Gyare and the Druk lineage emphasized the siddha-based tantric teachings and practices that are traced to Milarepa's second great disciple, Rechungpa Dorje Drakpa (1085-1161). This connection flows through Lingrepa Pema Dorje (gling ras pa padma rdo rje, 1128-1188) who was a married tantric practitioner, and more immediately in the form of a cycle of treasure texts concealed by Rechungpa that was discovered by Tsangpa Gyaré.

Tsangpa Gyaré's disciple Götsangpa Gönpo Dorje (rgod tshang pa mgon po rdo rje, 1189-1258) was a traveling musician and actor in his youth. He eventually became disillusioned with worldly life and sought out Buddhist teachings. Götsangpa spent many years in retreat and also traveled extensively to Buddhist sacred sites on the Tibetan plateau, such as Mount Kailash, where he established the definitive circumambulation route. He established sites in Lahaul, and travelled down to the Indian plains, most notably to Jalandhara, which is one of the twenty-four sacred sites associated with the Cakrasamvara tradition, and which is also regarded as a Śākta pịtha.

A né is considered to be hidden or closed until a spiritually advanced being makes it available for himself and others as a site for pilgrimage and practice. The opener of the Saurata né was a disciple of Götsangpa-Chöjé Shelgompa (chos rje shel sgam pa). ${ }^{12}$ Shelgompa was sent to Nako by his teacher to open this né, which the latter identified as one of the twenty-four places associated with Cakrasamvara. When Chöjé Shelgompa came to the region, people were unaware of the né and their proximity to it. The story goes that when Chöjé Shelgompa first came to the region, he asked what the name of the place was. The answer was "Embankment Mountain" (ri rags), but Shelgompa corrected the person, "no, this place is "the seat of the né" (gnas gdan) Continuing on to the village of Maling, he met an elderly woman, whom he asked, "What is the name of this place? She gave the name as

10 Tucci (Tucci 1988, p. 144) says that his informants said that the structure was dedicated to the mountain deity.

11 Klimburg-Salter (Klimburg-Salter 1990, p. 149) says that in Tucci's time Nako was predominantly Nyingma, but Tucci's own observations (Tucci 1988, p. 19, and map) indicated that Nako and the surrounding area were primarily Drukpa Kagyü. The paintings in the two mani wheel temples in Nako village are both adorned with images of Drukpa masters, and deities favored by the Drukpa Kagyü sect.

12 The transliteration here and throughout reflects the pronunciation of the Tibetan-speaking people of this region. 
Maling, but again he corrected his informant, saying “No, it isn't Maling, it is the outer fringe of the né" (gnas gling)." 13 Reaching the village of Nako, the pattern continued, with Shelgompa correcting his informant, "No, it isn't Nako, it's "the doorway to the né" (gnas sgo). He explains the auspicious location saying, "At the top is the eastern mountain, the lower part is the western mountain, in the front is the turquoise lake. At the rear is the constructed temple," the latter presumably referring to the 11th century structure attributed to Rinchen Zangpo.

\section{The Saurata Nékor}

The name Saurata is a Tibetan pronunciation/spelling of Saurāstra, which is one of the twenty-four pilgrimage sites named in the Cakrasamvara corpus. The pilgrimage guide calls the né Saurața, but among the inhabitants of Nako village, it is more commonly referred to Somang. This is likely to be due to Somang being the name of the incarnate lama who owns the site, and leads the yearly group pilgrimage there. ${ }^{14}$ Beginning in the village (Figure 2), the path climbs the ridge of the mountains to the east of the lake to a pass where it crosses to the other side of the ridge. As one begins the climb up from town there are rows of chörtens and mani walls, ${ }^{15}$ and a large new mani wheel ${ }^{16}$ that is wind-powered on the promontory that juts out overlooking the lake and the village. Just behind this, and presumably older, is a large cairn (la btsas) topped with a bundle of juniper branches adorned with white silk offering scarves (kha btags), that is probably a shrine to a local deity, though my informants did not mention it, and it is not mentioned in the pilgrimage guide. In front of this is a tall, stripped tree trunk with a tall vertical prayer flag (dar chen). From this point, the path is clearly marked and very well-maintained. This is so for the route for some time beyond the pass and on along the other side of the mountains as the path runs more or less level.

Just before the pass is the first of the self-arisen (rang byung $)^{17}$ stone features of the né. A tall narrow stone stands to the right of the path. On this stone is an image of Padmasambhava, with a demoness holding an eight-year-old child in her mouth, under his foot. It is said that when Chöjé Shelgompa began to explore this né, the forces of darkness rallied to try to stop him from his task. Here at the beginning of the route we see Padmasambhava appear in his well-established role of subduer of demons, aiding Chöjé Shelgompa in his efforts, not in bringing Buddhism to the region, but rather in opening up a new sacred space that will benefit others. Throughout the route, Padmasambhava is present to protect, encourage, and welcome Chöjé Shelgompa. Moreover, we see his mere presence here as a major source of the power that makes this a né.

Just up the path toward the top of the pass are two large standing stones, one leaning against the other. The lower one is said to be Dzambhala, the regent of the northern direction and the god of wealth. As is usual in his depiction, he holds a mongoose in his left hand. This is the most obvious feature that is recognizable in the rock, as the mouth of the mongoose is easily seen and there are two black dots on the stone that are its eyes. Lodged between the two large standing stones is a small, nearly square stone that is said to be a single dice. These are said to be messages, but just what the messages mean was not clear to my informants nor is it explained in the pilgrimage guidebook.

13 The word gling has a range of meanings referring to place, but one informant explained it as being like the fringe or border on an article of clothing, i.e., indicating an outer piece or place.

14 For a brief biography of Somang Rinpoché, see: http://www.drukpachoegon.info/rinpoche-biography/somang-tulkubiography.aspx.

15 These are piles of stones with the mantras of Buddhist deities carved on them. The mantra of Chenrezik (spyan ras gzigs, Sanskrit, Avalokiteśvara), the Bodhisattva of Compassion (om mani padme hum) are particularly prevalent, hence the name mani wall. For an examination of this mantra and its importance see Donald Lopez's discussion (Lopez 1998, pp. 114-34).

16 A chörten (chos rten) is the Tibetan form of the stupa. A mani wheel is large wheel with the mani mantra on the surface, and contained within. Spinning these, and/or circumambulating them, is a popular merit-making practice in the Tibetan Buddhist world.

17 A "self-arisen" feature is manifestation in rock thought to appear because of the sacred power of the place. These are a common feature of Tibetan pilgrimage sites. 


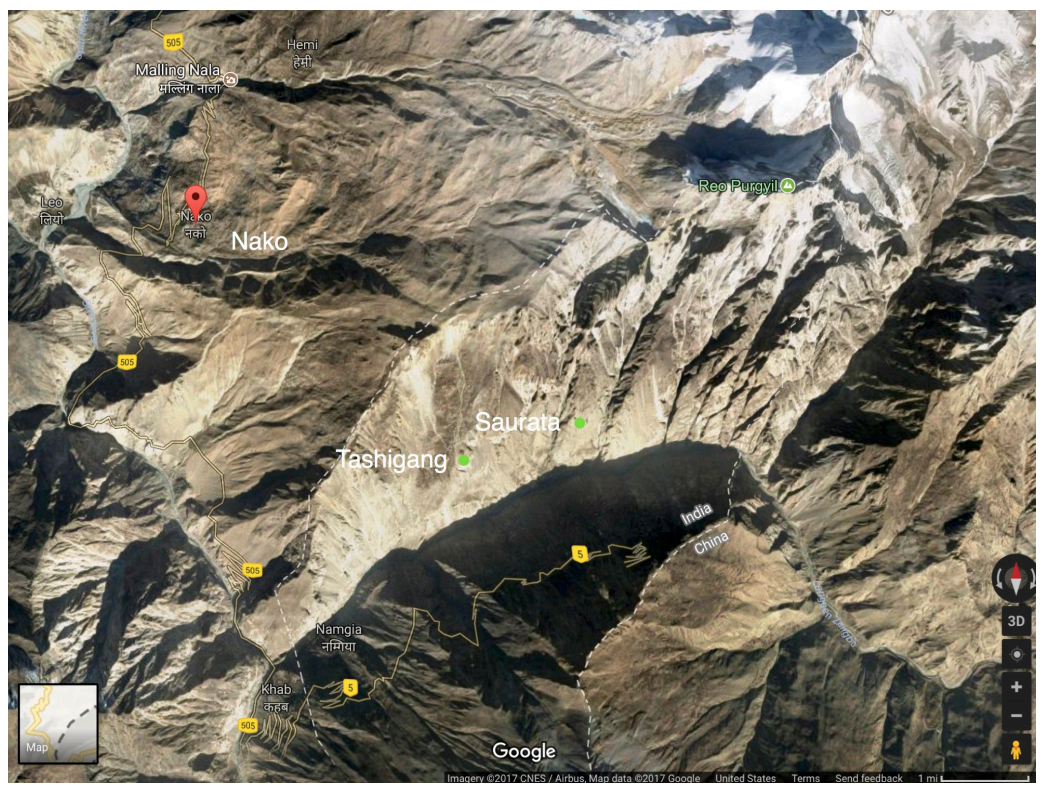

Figure 2. Map of Saurața in relation to Nako and Tashigang.

At the top of the pass is a large cairn (lab rtse) with many strings of prayer flags connecting the bundle of sticks and juniper branches with the surrounding peaks and boulders. Nothing was said about this monument. The three large rock columns surrounding the cairn are said to be like the three legs of the tripod of a local cooking stove. A large boulder just down the slope was said to be a copper cooking vessel that was used by the Buddha Saakyamuni and his entourage when they prepared food for a tantric worship gathering (tshogs mchod) here. This is one of two appearances of Śākyamuni at this pilgrimage site. About an hour further on there is a very large boulder with three deep indentations that are said to be the bodily imprints (sku rjes) of Guru Rinpoche and his consorts, Khandro Yeshe Tsogyel ( $m k h a^{\prime}$ 'gro ye shes mtsho rgyal) and princess Mandāravā, (Figure 3) who came here to welcome and encourage Chöjé Shelgompa. They gave him Dharma teachings and tantric empowerments, and showed him the way to continue.

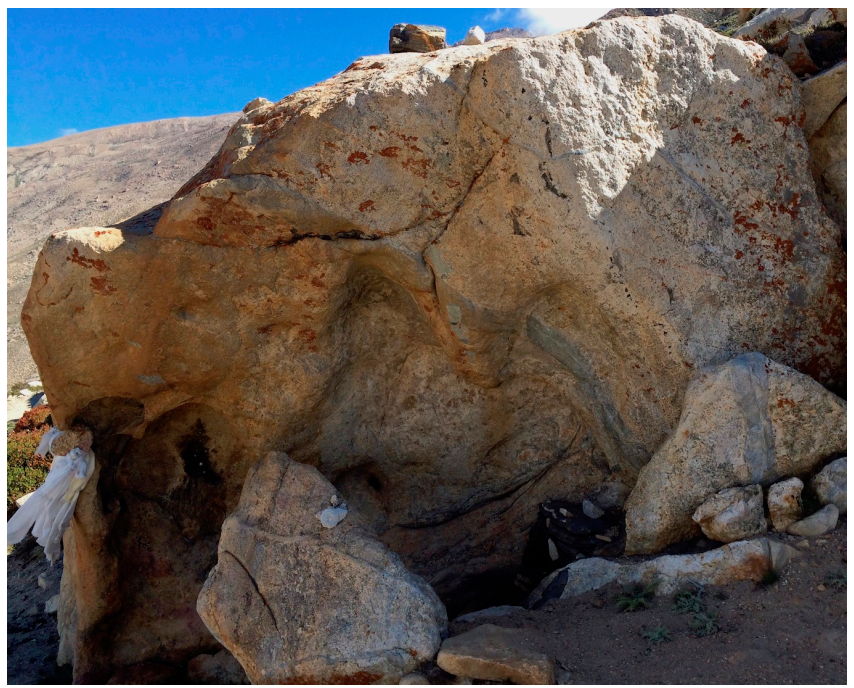

Figure 3. The body-imprints of Guru Rinpoché and his consorts. 
The imprints are quite deep into the surface of the boulder, and like most of the other self-arisen images, don't appear to have been colored or accentuated to make them more visible. The imprint of Mandāravā, however, is thickly coated with oil (a common gesture of worship along this pilgrimage), which makes the image more visible. There are also coins stuck to the surface (another common practice) where her face would be, and there are khataks wedged between the rocks at the edge near her. Yeshe Tsogyel's image is less clear, but there is a small stack of flat black stones at the bottom of it, with a few lighter ones placed on top of the stack. There are prayer flags strung between the top of the stone and others around and a wooden pole on the other side of the path.

About two hours later, one comes to a huge boulder on the exposed underside of which is said to be the imprint of Chöjé Shelgompa's hand grasping his walking stick. At this spot, khandromas hurled this boulder at Chöjé Shelgompa because they did not want him intruding into their territory. He said, "Don't do this!" and held up his walking stick, stopping the boulder and imprinting it with his hand. His command ended with the sound "a," which is an imperative particle in colloquial Tibetan, and this letter is said to be imprinted far up on the mountain's face above this spot. Further on, is a rock face with many small niches in it. This is said to be imprints of the Buddhas of the Forunate Aeon (bskal bzang gi sangs rgyas) who came here to welcome Chöjé Shelgompa. It is said that a virtuous and realized person will be able to see butter lamps burning in each of these niches. It is also at this spot where one catches the first glimpse of Tashigang (bkra shis sgang) monastery, which is situated along the route and is typically included in the pilgrim's itinerary. There is a ridge here at which pilgrims do prostrations in the direction of Tashigang and rest of the route further on. ${ }^{18}$

Tashigang requires a steep climb up from this point. The main structure is quite small, but there is new construction going on just below it. The focal point of the main assembly hall is a small image of Milarepa that is said to have been made by one of his disciples during his lifetime. He made three such images, and all three are said to be in the area of Hangrang. The other two are supposed to be in the possession of private individuals and only brought out occasionally, so this one is important because it is accessible. The image is said to have hair that grows back if cut. It is located in a cavity in the chest of a large statue of Shākyamuni, covered with a glass door. The shrine contains a number of other statues, including a large Guru Rinpoché with consort, and a finely detailed Chenrezik (spyan ras gzigs, Sanskrit, Avalokiteśvara).

Continuing on from Tashigang, the next site is a small spring coming down to the path from above, forming a small pool. It is said that there were a pair of tantric practitioners ( $d p a^{\prime} b o / d p a^{\prime} m o$, Sanskrit vīra/vīrā) who were living here, and they transformed themselves into the form of a brahmin couple. They did this in order to hide who they really were, specifically so that Chöjé Shelgompa would not recognize them or judge them. When Chöjé Shelgompa reached this spot, he was very hungry and thirsty. He did not know at this point where Saurata was, and he had not brought enough food and water. The couple either created or revealed this spring, and offered water to Chöjé Shelgompa, saying that it would be like the blessed water that is given during a tantric empowerment or like the elixir of immortality. Drinking his fill of this water, Chöjé Shelgompa felt completely satisfied and energized. A little further on, there is a naturally-arisen image on the rock face of the old Brahmin couple (Figure 4).

Climbing up toward the final destination, there is a place where one sees an image in the mixture of light and dark stone far up on the rock face. Against a white background there is a long thin dark shape coming down that is said to be a poisonous snake. Just below, but rising up into the white area are two dark shapes that are said to be a golden fish and a turquoise fish. The white background is said to be a lake of milk. The meaning of all this was not explained by my informants or the pilgrimage guide, other than that it is a landmark to help locate the next site, the spring created by Guru Rinpoché.

18 There is no mention of Tashigang in the Saurata pilgrimage guide, but my informants said that people generally include it. 


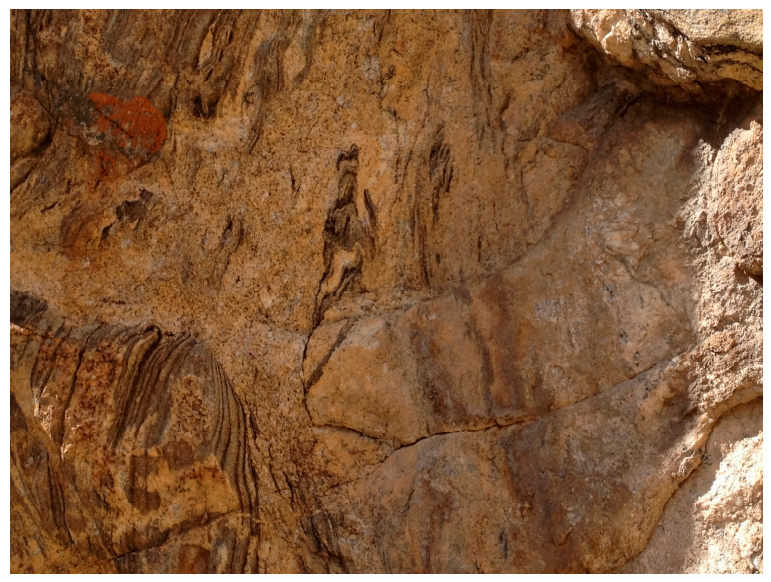

Figure 4. Image of the Brahmin couple on the rock surface.

The spring known as tsechu (tshes bcu) is the last site before arriving at Saurata né. Guru Rinpoche created a spring here for Chöjé Shelgompa, who, when he drank this water, became so happy that he said it was like the feast offering (tshog mchod, Sanskrit: gana püja) celebration on the tenth day of the lunar month in honor of Guru Rinpoché, thus this is what this spring is called. This site is more elaborate than the previous spring, with mantras of Guru Rinpoché painted and carved on the large boulder, khataks tied around the tree, and prayer flags decked across the site. The spring itself, however, was not flowing. There was a plastic soda bottle propped up where the water should have been coming, but there was no stream and the bottle was empty.

Finally arriving at the heart of Saurata eleven hours after departing the village, one enters through a rough wooden gateway surrounded by lush greenery studded with small dandelion-like flowers (Figure 5). The site is a short distance up the valley from the confluence of the Sutlej and Spiti rivers, directly across the Sutlej gorge from Shipki pass, which is the border between India and China and is now controlled by the Chinese military (Figure 6). The space is situated on a steep hillside, with several levels of flat ground on which the structures sit. On the level where one enters is a three-room guesthouse and the caretaker's quarters. The caretaker's quarters consisted of a fairly large room with a stove and sitting and sleeping space. Behind this room was a cave, which is one of the five main caves of the né. At first sight the cave seemed to be no more than a storage area, with several car batteries, and numerous other practical things piled up, though there were several khataks draped across the space, including one hanging from a spot in the rock ceiling. It was only later that we learned that this was one of the caves of the né circuit.

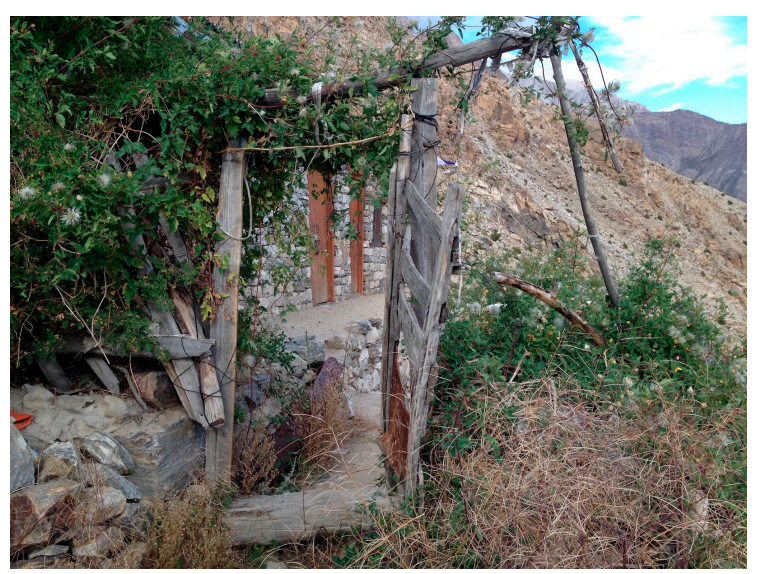

Figure 5. Entrance gate to the circuit of the five caves. 


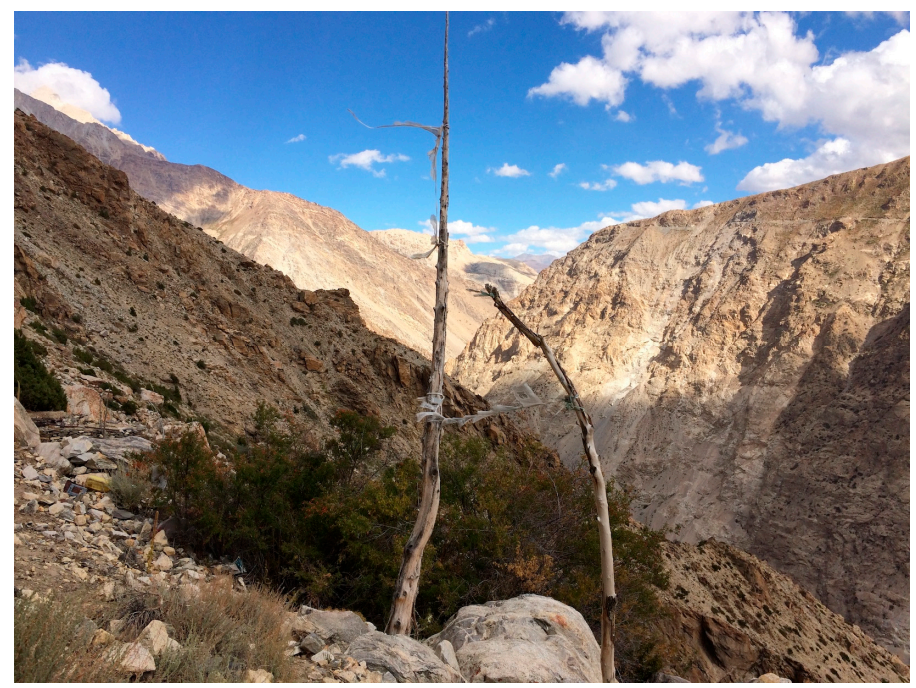

Figure 6. View from Saurata across the Sutlej river gorge. The Chinese border is on the ridge.

Up a level, and further on than the caretaker's quarters is the shrine room that seemed to serve as the focal point of regular worship at the site (Figure 7). The caretaker filled the water bowls and lit the oil lamps daily, and the room was well-maintained. It seemed however, that there was not always a caretaker present, as we had to wait for several weeks to do the pilgrimage for the caretaker to return to Saurata from his home in Nako. In a windowed vestibule, there is a small rock ledge with oil lamps, and numerous coins pressed on the rock wall above. The stucco-like wall of the vestibule was said to be the result of Chöjé Shelgompa blowing his nose in his hand and flinging it out the door of the shrine, creating the rough surface of the wall. Entering the tiny doorway one comes to the shrine itself, which hold five or six people. The central image is an eleven-headed, thousand-eyed Chenrezik (spyan ras gzigs, Sanskrit: Avalokiteśvara). In front of it are a few smaller images, including a Guru Rinpoché, and photos of the current and previous Somang Rinpochés. This is the incarnation lineage associated with the site. Up on a cabinet to the left of the main image was a large book in very poor condition and several others. On a small puja table near the window was a book that was said to be the original of the pilgrimage guidebook (gnas yig) of Saurata. The text in the appendix here is the translation of the transcribed text done by Lama Ngawang Negi.

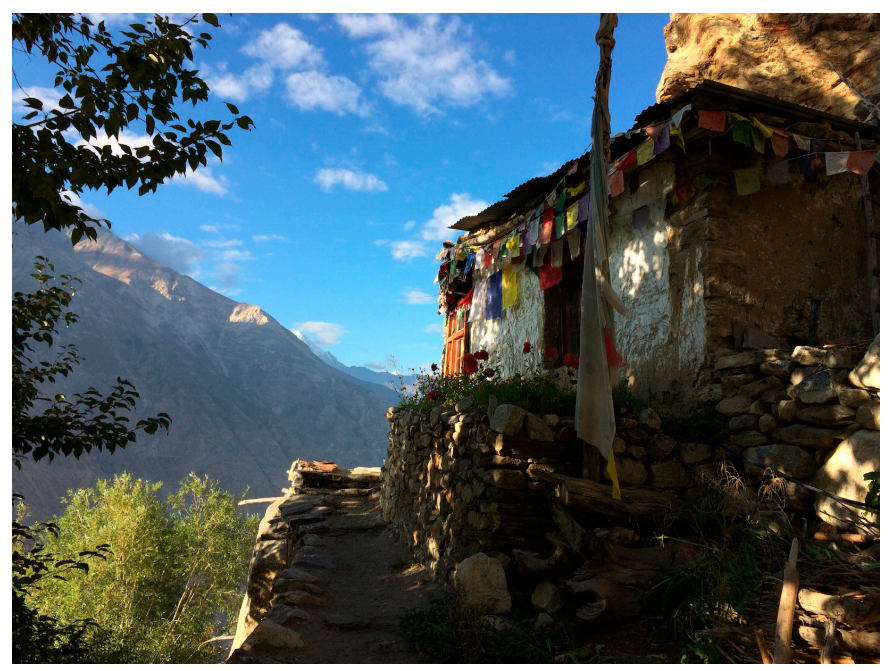

Figure 7. The Shrine Room. 
Towering over the entire site are two massive stone formations, each split into two conjoining parts. One is said to be a Denchok "father-mother" deity couple in sexual embrace (yab yum) and the other is Tamdrin (rta 'grin, Sanskrit: Hayagrīoa) and Dorjé Pakmo (rdo rje phag mo), Sanskrit: Vajravārāhh $)$. Higher up, but often hidden by clouds, is a peak called Khorlo Dompa because the stone bears his image along with his consort and there is a lake in which the image is reflected. Surrounding the peak is a path that the khandromas circumambulate. This spot is said to be difficult to reach but is visited by some pilgrims. It is mentioned in the pilgrimage guidebook in reference to Drölma Cave, but is not emphasized as a central feature of the né.

In addition to the temple, there are the residence of Chöjé Shelgompa and numerous footprints (rje zhabs) and "self-arisen" (rang 'byung) images along the way. The central features of the né, however, are the five caves. The organization of the caves into a mandala-like form is typical of many Tibetan pilgrimage sites, and is often discussed in terms of this functioning to "buddhacise" a perhaps-previously indigenous sacred site. ${ }^{19}$ The center is Yeshe Gönpo (ye shes mgon po, Sanskrit: jūannanātha) Cave, with Drölma (sgrol ma, Sanskrit: tārā) Cave in the east, Pakmo Cave in the south, Tamdrin Cave (rta' grin phug) in the west and Jakhyung Cave (bya khyung phug) in the north. Of the five, Pakmo cave is actually far away and seldom visited by pilgrims. In it there is the self-arisen breast of Dorje Pakmo. It was said that the cave was quite far from the center of the circuit and the breast was not very clearly manifest, so few include it in their circuit. The rest of the caves are quite close together, the circuit taking under three hours to complete.

The first site one comes to is Tamdrin Cave. The route circles clockwise from the west (exempting the southern cave) and finishes in the center. This cave is where group rituals are performed when a large local group, led by Somang Rinpoché, comes to Saurața during full moon in May/June each year. Tamdrin is often considered to be an emanation of Chenrezik, as a wrathful form. He is a widely encountered protective deity and meditational deity (yi dam, Sanskrit: iștadevatā) throughout Tibetan and Himālayan Buddhism. There are paintings of him in two of the three Nako village shrines. There is a self-arisen image of Tamdrin in the ceiling of the cave, but my guides did not point out any features, other than that it was in a rather unkempt state.

From Tamdrin Cave, one goes back out the gate and climbs up and begins the clockwise circumambulation path. The first self-arisen image is of Dorje Pakmo's breast. It is a small portion of a medium-sized boulder that is easily spotted since it is darkened from having been rubbed with oil. A little further on is a large flat boulder on which there are gouges that are said to be from when Buddha Sākyamuni cut up a demon on the rock's surface. Next, one comes to a very large vein of smooth white rock coming down from the mountain with the appearance of a river. It is quite striking against the darker and more gravelly surroundings-six to eight feet across and hundreds of feet long from beyond where one can see above to over the rim below. Where the path crosses this rock "river" is a small pool of water that is said to be the khandromas' washing basin. Just after this feature was a large cleft rock that was said to be the vulva of a khandroma (Figure 8). It was nearly five feet tall and pilgrims had rubbed one side of it with oil and affixed coins. I was told by one informant that sometimes a spring flowed from this feature, though there was no evidence of that when we were there.

19 See Katia Buffetrille (Buffetrille 1988) for a discussion of this process. 


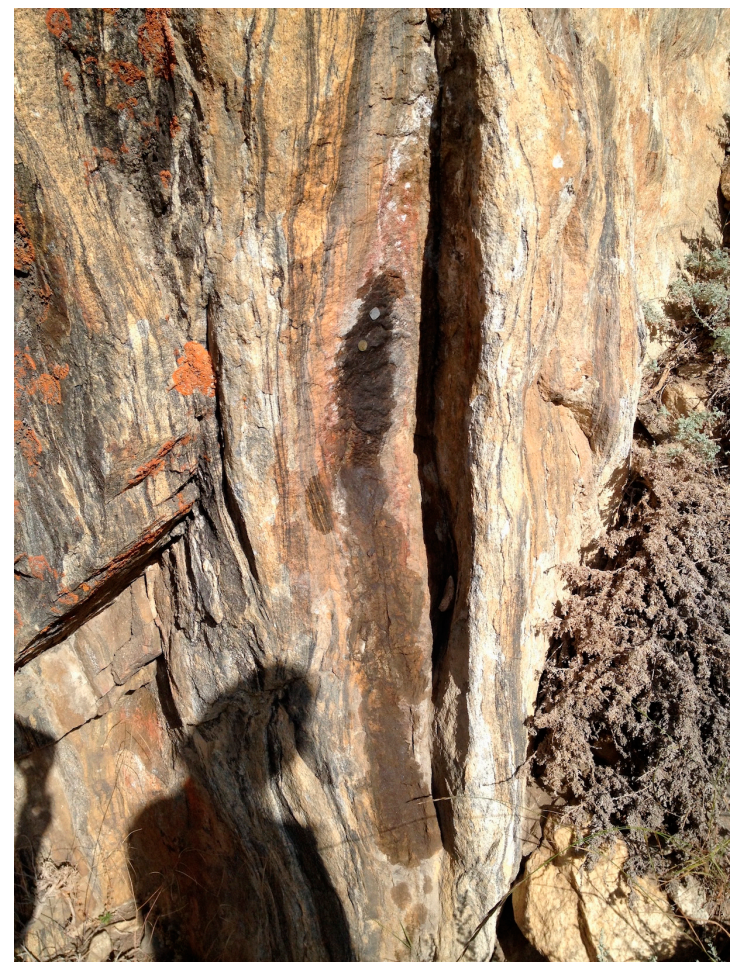

Figure 8. The khandroma's vulva.

The next major self-arisen image is a large and prominent wrathful image of Guru Rinpoché surrounded by flames. ${ }^{20}$ One then comes to Jakhyung (bya khyung, Sanskrit: Garuda) Cave. The cave is partially walled-in, with four chörtens (chos rten) on the outer edge of the cave floor. Against the inner wall are hundreds of clay votive icons ( $t s a t s a$ ) that were made by monks who stayed in the cave for an extended period of time in the past (Figure 9). On the ceiling of the cave is a self-arisen image of Jakhyung's head and wings. The image has been rubbed with oil, and coins have been pressed on the surface (Figure 10) as worship by pilgrims. My informants said that a wish made in this cave would definitely be granted, as long as that wish would have no negative impact on anyone. The next stop is said to have been Chöjé Shelgompa's residence. This is a well-built dwelling of several rooms, partially built into a cave in the cliff face. Unlike many openers of nés, Chöjé Shelgompa never left this place, or if he did, he returned to live out his days here. My informants said that when he died, the Buddhas of the Five Lineages (rgyal ba rigs lnga) came and prepared his corpse for the funeral. Markings on the wall are said to have been made by the Buddhas as they performed this service for Chöjé Shelgompa. The pilgrimage guide book says that Chöjé Shelgompa "feigned illness" at the end of his life and transformed into light, which was imprinted on the rock wall of the cave. It also mentions the imprints of the Five Buddhas "pulling up and pressing down,"without elaboration on what they were doing. My informants did not point out the image from Chöjé Shelgompa's transfiguration, and I did not see it. These two elements of the story suggest that Chöjé Shelgompa left behind bodily remains, but I saw no large chörten and none was mentioned.

20 My informants said this this form was Guru Drakpur (guru drag phur). Guru Drakpur is a wrathful form of Guru Drakpo (guru drag po) discovered as a treasure teaching (gter ma) by the great 16th Drukpa hierarch Pema Karpo (padma dkar po, 1527-1592). The pilgrimage guide identifies the image as Dorjé Drolö ( $r$ do rje grol lod), one of the eight primary manifestations of Guru Rinpoché. 


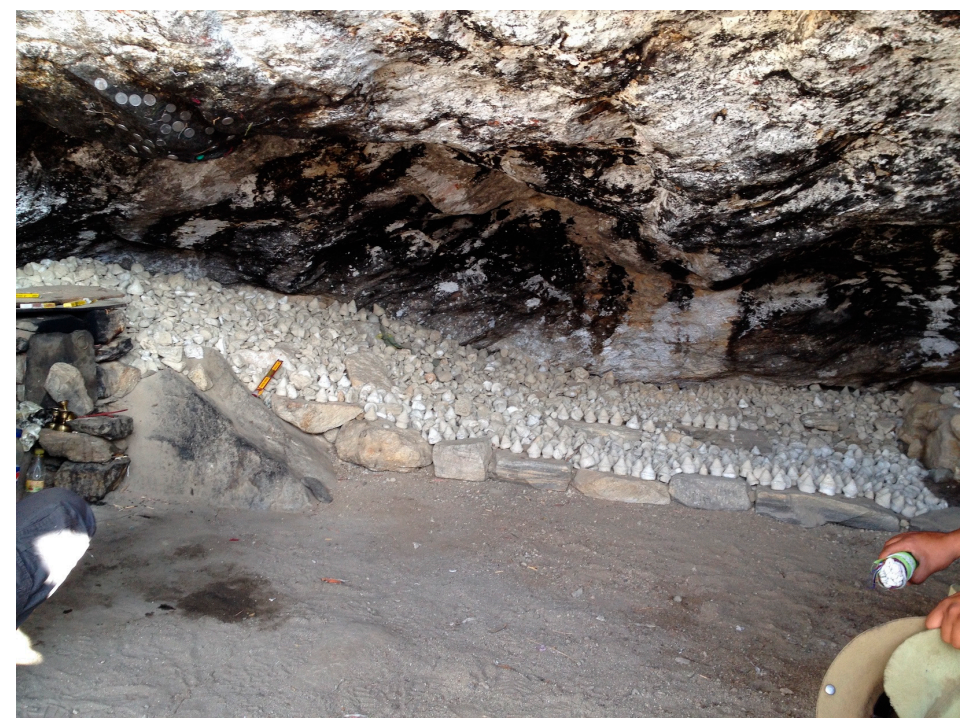

Figure 9. Tsa-tsas in Jakhyung cave.

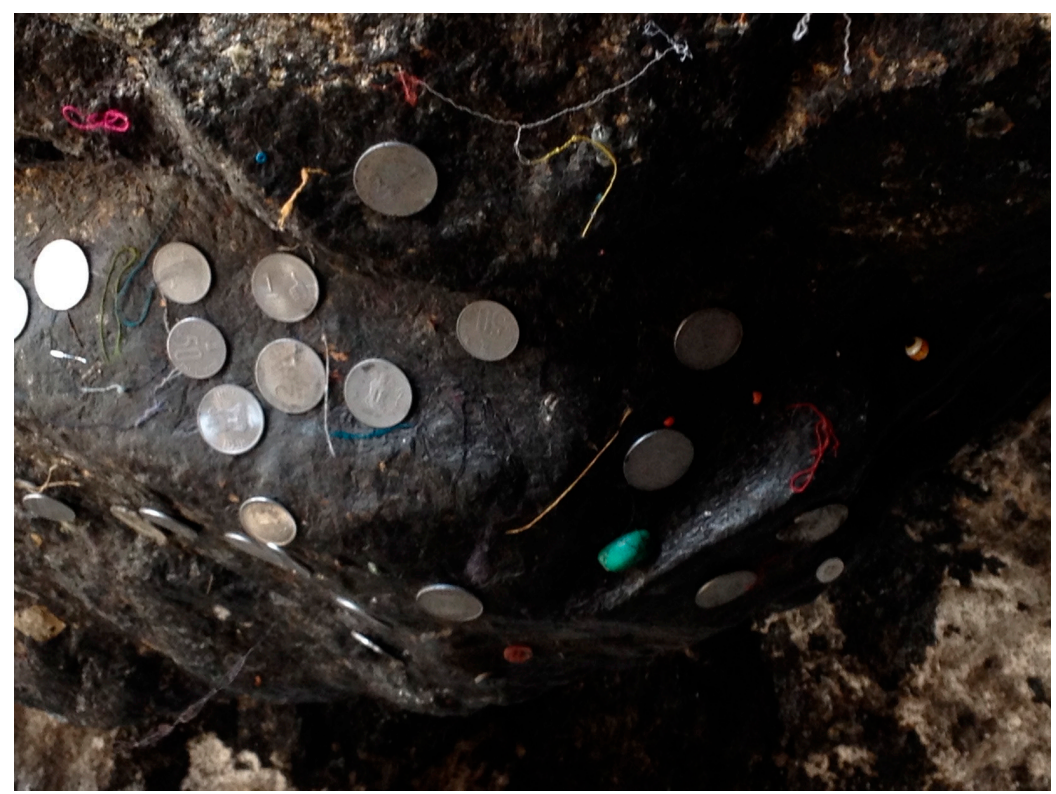

Figure 10. Coins affixed to Jakhyung's head.

Moving on from Chöjé Shelgompa's residence, one comes to a self-arisen image illustrating the well-known story of Milarepa and the hunter Khyirawa Gönpo Dorje (khyi ra ba mgon po rdo rje). The image is quite high up on the rock face, so pilgrims apply oil and coins lower down on the rock. Next is another prominent self-arisen image of Guru Rinpoché on the cliff face. He is said to be riding on the sun, so like the previous image of him said to be surrounded by flames, the dark image of the Guru stands out against the red rock surrounding it. Above the image is a round indentation in the rock in which is said to be concealed the golden key which some holy being in the future will use to open a new né. A little further on from here is a large cave said to be the palace of the Yama Rāja, the Lord of Death. On the wall of the cave is a light patch of rock with black spots on it. The light surface is said to be the mirror on which one's good and bad actions in this life are tallied as white and black 
stones. ${ }^{21}$ Yama Rāja judges the person after death based on this accounting, and one goes accordingly to heaven or hell. This image is said to teach this important lesson. Above the cave is a small hole, with a red streak coming down from it. This is said to be the menstrual blood of an eight-year-old khandroma (Figure 11).

The next cave is Drölma Cave. One day while Chöjé Shelgompa was living in his residence, he heard a man's voice coming from the cave below while he was meditating. Going to investigate, he looked into the cave and saw the twenty-one Tārās dancing in a circle around Khorlo Dompa. Upon being seen, Khorlo Dompa flew up into the rock of the ceiling, blessing the rock and leaving a self-arisen image of his "secret part," i.e., his phallus (Figure 12). The twenty-one Tārās dissolved into walls of the cave. Women who are unable to conceive come to this place to become fertile, and the cave is said to bestow blessings on all who come there. Just inside the door is a broom with which to sweep the dirt of the floor as one leaves. The next person who enters looks at the floor, and if she is lucky, she will see footprints of khandromas in the dirt. One of my informants noted that earlier, the sightings of the footprints was quite common, but more recently it was becoming less so. At the rear of the cave is a small passage between an upper and lower boulder. It is said that if one is without sin, he or she will be able to squeeze through the space. A sinful person will not be able to pass through.

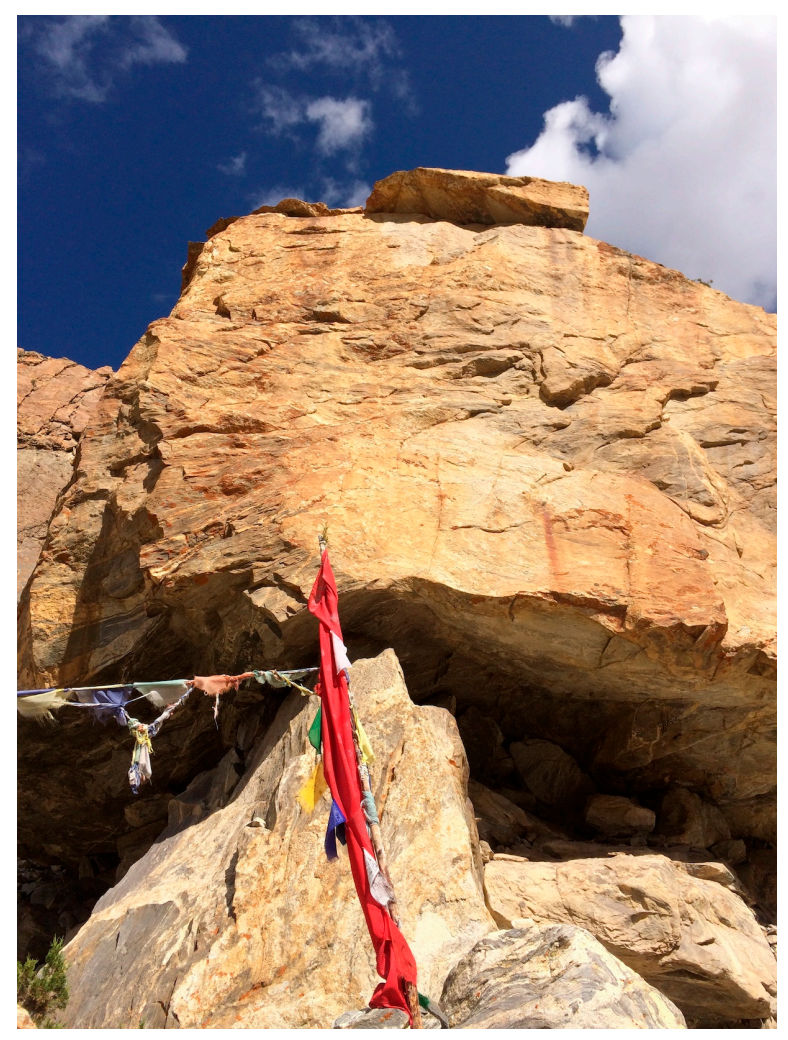

Figure 11. The palace of Yama Rāja and the menstrual blood of the khandroma.

21 This scene illustrates a common Tibetan Buddhist understanding of the judging of one's past actions after death, determining the subsequent rebirth. The pilgrimage circuit at Amnyé Machen also has this feature (Buffetrille 2007). For a classical expression of this narrative, see the account in the so-called Tibetan Book of the Dead (Coleman and Jinpa 2007, pp. 279-81). 


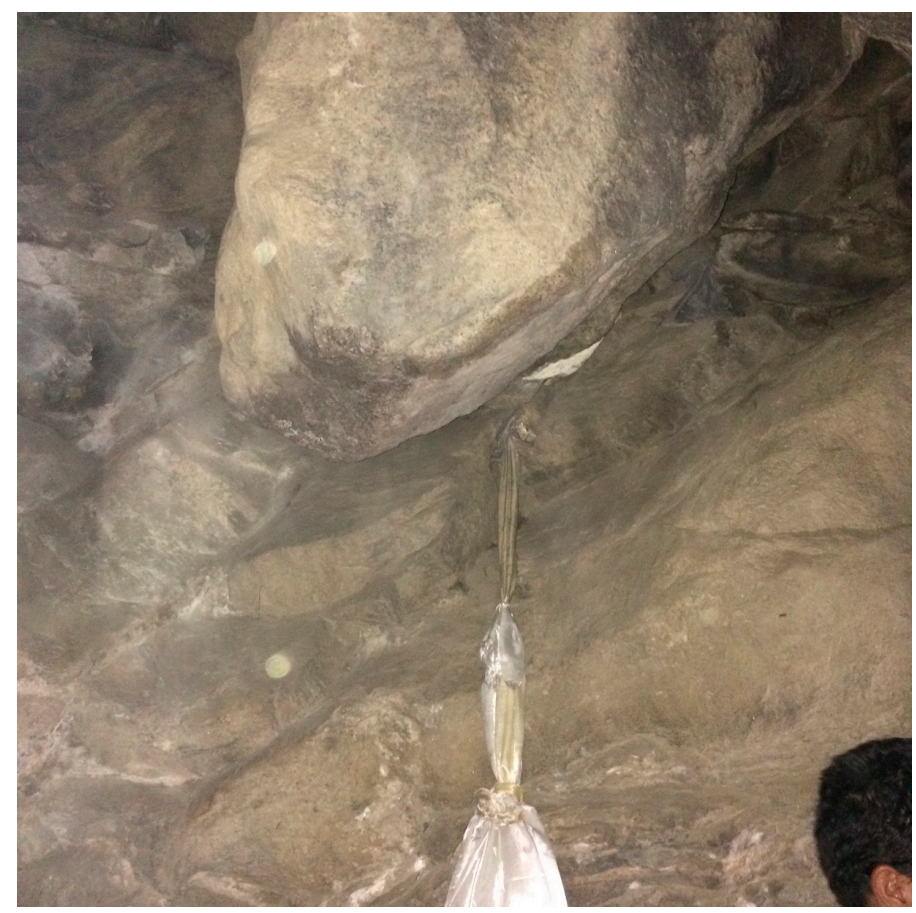

Figure 12. The phallus of Khorlo Dompa.

Finally, one reaches the center, Yeshé Gönpo Cave. "Yeshé Gönpo" is another name for Mahākāla, and the Drukpa lineage generally emphasizes the four-armed form of this protector and yidam. This is a very large and well-appointed cave, with a wooden floor and central altar (Figure 13). When a large group of people do the pilgrimage in May/June led by Somang Rinpoché, he leads the puja and feast offering in this space. Just inside the door is a small stove, that conceals a self-arisen letter "āh" on the floor. This was placed here to prevent people from stepping on the image. In the ceiling of the cave is the self-arisen face of Yeshé Gönpo (Figure 14).

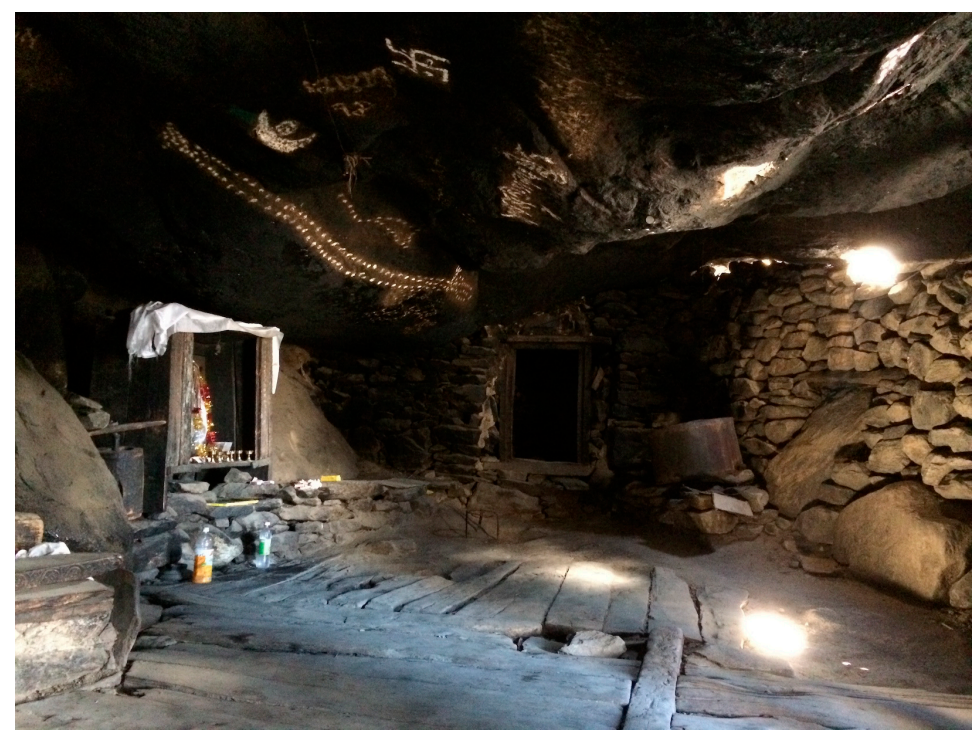

Figure 13. Yeshé Gönpo Cave. 


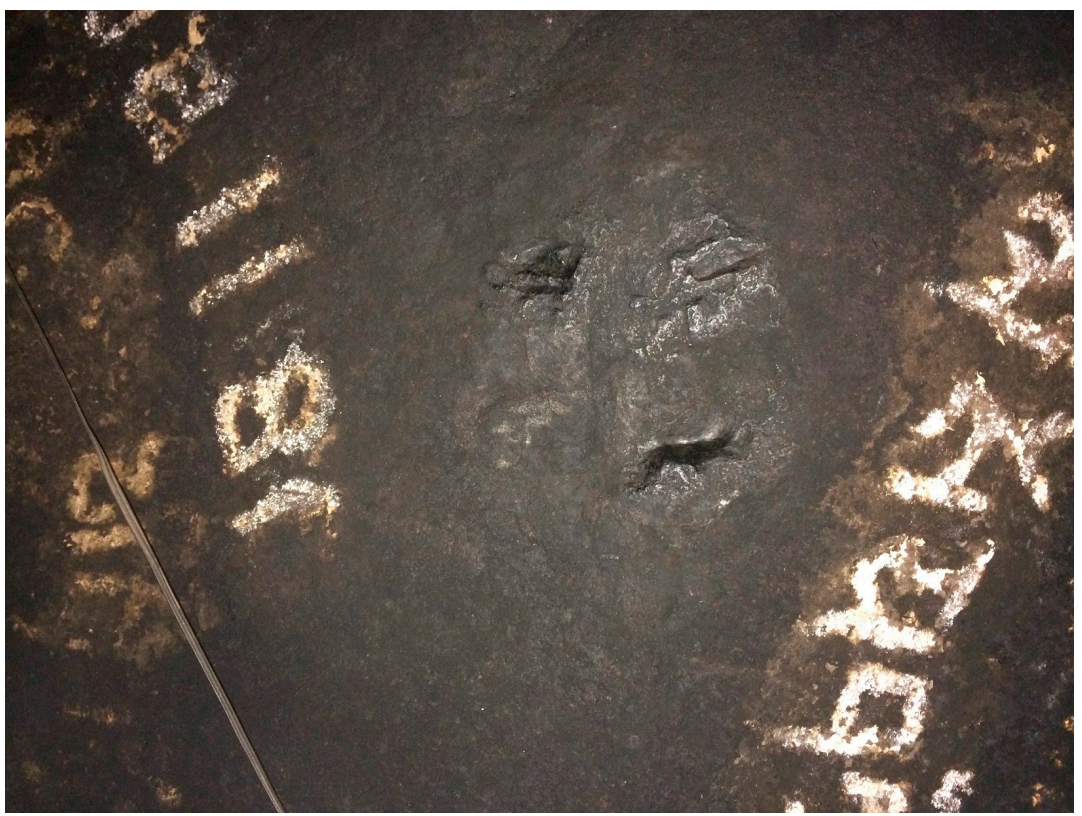

Figure 14. The face of Yeshé Gönpo.

\section{Common and Unique Features}

The characteristics of the Saurata né are largely consistent with those found at other sacred sites across Tibetan cultural regions. The most notable is the identification of the site as one of the twenty-four pițhas of the Khorlo Dompa mandala. Like other major pilgrimage sites on the Tibetan plateau, particularly Tisé, Tsari, and Lapchi, ${ }^{22}$ Saurața's transformative power (byin rlaps) arises fundamentally from Khorlo Dompa, the other deities of the mandala, and the presence of the khandromas. Saurata also grants blessings due to the spiritual presence of great yogis, such as Padmasambhava, Milarepa, and Chöjé Shelgompa.

The extensive presence of lithic hierophanies is common to the major nés as well. Footprints and other body impressions, self-arisen images in stone, and edifying or auspicious scenes in stone are found at Tisé, Lapchi, and Tsari, as well as other nés. The keyhole containing the key to a further sacred land is also present at Tisé. (Huber and Rigzin 1999, p. 129). The perhaps most remarkable stone features, the khandoma's vulva, and the phallus of Khorlo Dompa, have parallels at both Tsari (Huber 1999b, p. 67) and Lapchi (Huber 2007, p. 267). The same is true of springs and other water features, which dispense blessed water, or "attainment water," and Tisé features a khandromas' bathing pool (Huber and Rigzin 1999, p. 135).

Perhaps the most significant difference between these great Khorlo Dompa-associated nés and Saurata is the insignificance of the mountain in the circuit. At the other sites, the peak is considered the center of the mandala and the palace of the Khorlo Dompa and his retinue. This is particularly remarkable in that the mountain, Riwo Purgyel, the highest peak in Himachal Pradesh, towers above the Hangrang region, and is regarded as its territorial god (yul lha). The process of "mandalisation" mentioned above would suggest that this peak would, over time, have been overwritten with the Khorlo Dompa narrative either partially or completely, but this has not occurred. Other remarkable peaks across the Tibetan plateau (including the nearby Kinner Kailash peak) came to be local instantiations of the paradigmatic Khorlo Dompa peak, Tisé. While this "mandalisation" has occurred

22 For a translation of the pilgrimage guide to Tisé, see Huber and Rigzin (Huber and Rigzin 1999). For Lapchi, see Huber (Huber 2007). For a comprehensive study of Tsari that includes translations of portions of the pilgrimage guide, see Huber (Huber 1999b). 
to varying degrees at major sites in Tibet, for whatever reason Riwo Purgyel has resisted this process and plays no part in the Saurata pilgrimage that lies on its slopes. As an interesting aside, I was told by two of my informants that the position of the Nako oracle of Riwo Purgyel had been vacant for some time. The position was traditionally held by a member of one of several families but no one had stepped up to take on this responsibility because of its stringent purity demands. I was told that the families in question had recently encountered misfortune because of this dereliction of duty. Nonetheless, Riwo Purgyel still had no voice as of the time I spent in Nako. While the yul tha has so far resisted "buddhacization," the deity's standing in the region is uncertain.

Lakes are typically also central, with the mountain being the male feature and the lake being female (Buffetrille 1988, p. 18). The lake in Nako is part of the village circumambulation route, being a place where Padmasambhava once meditated, but other than being mentioned in the pilgrimage guide as an auspicious feature outside the né, it does not play a part in this site.

Rather than a mountain serving as the center of the mandala, at Saurata it is a cave, in a circular arrangement of caves. Caves are common features at Tibetan pilgrimage sites, but with rare exceptions, they are seldom the focal point of the né. ${ }^{23}$ Though it has become commonplace in the scholarship on Tibetan pilgrimage that "mandalisation" serves as a traditional interpretive concept imposed upon Tibetan sacred sites, it important to note here that while the caves are laid out in a mandala-like form, this is not a manḍala in the same sense as when the Khorlo Dompa mandala is overlaid on a mountain and its surrounding features. Saurata is itself held to be one of the twenty-four sacred sites of Khorlo Dompa Body Mandala, but there doesn't seem to be any sense that it is regarded as a mandala itself. The Saurata pilgrimage guide never uses the word "mandala" (Tibetan: dkyil 'khor) to describe the caves, it just locates them at the cardinal directions.

The deities of the five caves at Saurata are also found at the other great pilgrimage sites in Tibet, but it is noteworthy that since the five caves form the core of the site, one would perhaps expect the central cave to be Khorlo Dompa, but he appears only in the narrative about Drölma cave. The relatively-near peak called Khorlo Dompa, surrounded by the khandromas, is said to be the palace of the deity in the description of the Drölma Cave, but few make the strenuous trek up to this spot, thus it is not central to most pilgrims' performance of this nékor. The presence of Drölma herself is attested to at the Tsari and Tisé pilgrimage routes.

Caves and lithic hierophanies of Dorjé Pakmo are found at the major pilgrimage sites, and this should not be surprising as she is the consort of Khorlo Dompa in the Cakrasamvara Tantra. In the description of the twenty-four pitthas of the Khorlo Dompa mandala, the deity consort of the goddess of this site is Tamdrin/Hayagrīva (Gray 2007, p. 60), but that this is the reason for his presence at Saurata is speculative. That he is a popular meditational deity (yidam) across the sects of Tibetan Buddhism is enough to explain his presence here. The same can be said of Jakhyung (Sansrit: Garuda), and he is also an important pre-Buddhist and Bön meditational deity. Yeshé Gönpo, or Mahākāla, appears in the pilgrimage guides of the major né. Yeshé Gönpo is a protector deity, but he is of the transcendent protector class so he can also serve as a yidam. The Drukpa lineage observes the practice of Four-Armed Mahākāla (Yeshé Gönpo) as one of its core practices. There are many depictions of Yeshé Gönpo in the shrines in Nako Village, and the contemporary importance of this deity can be seen at the monastery in Bhuntar, in Kullu district, Himachal Pradesh, where Somang Rinpoché currently lives. Two subsidiary temples have recently been built flanking the main assembly hall: one of Khorlo Dompa, and the other of Yeshé Gönpo.

My informants told me that Saurata offered rewards both worldly and mundane. In, fact, one informant told me that just taking seven steps toward Saurata brought blessings. Throughout the route there were features that were said to be perceived differently depending on whether one was

23 The pilgrimage guide to Bön Kongpo Mountain gives prominence to a mandala-like arrangement of five caves (Ramble 2007b, pp. 165-72). The Drigung Powa pilgrimage features a massive cave as its most important feature (Kapstein 1998, pp. 109-10). 
a holy person or an ordinary one. Some of the particular features were said to have more specific benefits. Jakhyung Cave was said to grant any request that was made without malice. The phallus of Khorlo Dompa in Tārā Cave would grant progeny to the childless. The narrow passage between the boulders at the back of the cave demonstrated one's being without sin-assuming he or she makes it through.

The pilgrimage guidebook similarly states that visiting the né granted blessings, primarily because of the empowerment as one of the twenty-four pitthas of the Khorlo Dompa mandala, because heroes and khandromas gather there, and because of the attainments of Chöjé Shelgompa, who opened the place for future pilgrims and who lived out the rest of his life there. The site grants the accumulation of merit and the purification of pollution (grib). For the fortunate, meditative accomplishment and understanding will increase and for ordinary sinful people, evil will be dispelled. The guidebook claims that Saurata is unique in that it turns the mind of all who come there to the dharma.

\section{The Impact of Modernity on Himālayan Pilgrimage}

Unlike pilgrimage practices and sites in Tibet, pilgrim's activities have endured unbroken on the Indian side of the Indo-Tibetan border, but it too has been affected by modernity. Saurata is a relatively minor and regional né, but it is important to the people of Hangrang, and it is part of a multi-site pilgrimage route that takes in the late $11^{\text {th }}$ century monastic complex, Tashigang, and a nearby Padmasambhava site called Tirasang. Shortly after independence in 1947, India restricted travel to Kinnaur and Spiti due to their proximity to the Tibetan, and then Chinese border. Restrictions were lifted in 1992, though foreign tourists still have to get a permit for regions closest to the border, including Hangrang. Since 1992, tourism has increased significantly, though for most Nako is a brief stop before going on to the better-known ancient monastic complex at Tabo. Nonetheless, for better-informed and more adventurous tourists, Saurata has become a destination. The influx of tourists is contained to some degree by local efforts, most notably the Nako Youth Club, which offers accompanied tours. Some, however, undoubtedly make the journey unaccompanied. Graffiti can be seen at some points, including on the stone face just outside Drölma cave. My informants bemoaned this kind of behavior, as well as other types of bad behavior that did not treat the site with respect and reverence. They told me that some of the phenomena, such as the appearance of khandroma footprints in Drölma Cave and spontaneous arising of nectar in rock indentations had decreased in recent years. Like many in Lahaul and Spiti, they are also concerned about the impact of the increase in tourism that will inevitably come when the tunnel through the first range of the outer Himalayas is completed in the next few years. These factors, along with the perceived "Indianization" or "Hinduization" being propagated in the government schools are seen as eroding local culture and identity. Local traditions such as the pilgrimage to Saurața are considered by some to be under threat. These concerns, voiced to me over a decade of visits to Nako village, were a primary motivation in undertaking this study.

Acknowledgments: The research for this project was supported by a one-semester sabbatical from Northern Arizona University and a Fulbright-Nehru Academic and Professional Excellence Award (Research). No funds from either source were used for covering the costs to publish in open access.

Conflicts of Interest: The author declares no conflict of interest.

\section{Appendix A}

NB: This is a translation of the hand-transcribed and then word-processed text prepared by Lama Ngawang Negi (Anonymous n.d.). The original text is in the shrine room at Saurata, but I was unable to consult it. The text translated here contains a number of regional word usages/spellings, and perhaps scribal errors that make some of the translation speculative.

\section{The Guidebook to the Great Place of Pilgrimage, Saurața.}

To lay out in order the guidebook to Saurața, the great pilgrimage, first, the Conqueror Götsangpa made a prophesy to his disciple Chöjé Shelgompa, "Son, in the West through Haho Peak, you will 
tame this great land of pilgrimage, which is one of the twenty-four places," thus he prophesied. Then, from Bellows Pass, he went to Ma. Having arrived at Mushroom Plain, he searched for one rock for a stove in order to make food. He did not find one, but all the area was full of light. Then, he saw Ma Pass, and he asked, "What is the name of this country?" Someone said, "The name of this is Embankment Mountain. He said, "It isn't Embankment Mountain, it is "the seat of the place of pilgrimage (gnas gdan)." Then he went onward, and having arrived at Maling, he asked, "What is the name of this place." Someone answered, "Maling." "It isn't Maling, it's the "fragment of the né" (gnas gling) Then he went onward and arrive at Nako. He said to an old grandmother who was staying in a residence there, "What is the name of this place?" The answer was "Nako." "It isn't Nako, it's "the doorway to né" (gnas sgo). At the top is the eastern mountain, the lower part is the western mountain, in the front is the turquoise lake, at the rear is the constructed temple. This place has an extremely auspicious set of circumstances."

From there he strove upward, and having arrived at a white stupa, a roar sounded from a white conch shell, which is said to be the spreading of the teachings of the white dharma, and the conch fell and slipped away. Here, there is a footprint of Dorjé Chang. Then Chöjé Shelgompa went up, and having arrive at mani wall, a black conch sounded, and this is said to be the disappearance of the demonic teachings. Up from there, within a stack of rocks, there is a self-arisen image of Guru Rinpoché, trampling a demoness under his foot. There is a rock that is a self-arisen image of Dzambhala, and between these two is a dice that is said to be the karmic maturation of wrongs againsts one's father and mother. Behind that rock, on top of a hearth of three kinsmen is a bronze cauldron used to make tea for an assembly of monks, is a lion's mouth. By going further on from here, is the Orgyen Body Imprint. Here, Guru Rinpoché, Khandro Yeshé Tsogyel and Divine Consort Mandarava greeted Chöjé Shelgompa, gave him dharma teachings, and conferred tantric initiations. They said, "Son, your path from here is ready," and having shown him the path, the three, Guru Rinpoché and his consorts, dissolved into the rock, creating a self-arisen image. Thus, this place is renowned as the Orgyen Body Impression. Going on from here one arrives at the hand-staff image. The fine top ornament of the khandromas was rolled down. Chöjé Shelgompa said "Mother Khandromas, don't do this with the top ornament." He supported it with his hand and thumb and left an imprint of this and his staff in the rock. So, the name given to this place is "hand-staff." From this, there is a self-arisen "āh" up on the rock.

Going down from here, one arrives at the ridge of prostration. Chöjé Shelgompa was welcomed by the thousand Buddhas of the fortunate eon, who dissolved into the rock. At this place is the Thousand Buddha Bodies self-arisen image. At auspicious times, a holy person will see the shining of many-colored offering lamps. Going on from there, moreover, there is a self-arisen image, from the Conqueror Jampa Gönpo welcoming him. Going on further from there, one arrives at the place of the Brahmins. A male and female hero, who had disguised themselves as brahmins, welcomed him and said, "Son, we will make your thirst water" and having said this they made his attainment water. This water was excellent in smell and taste. On the rock is a self-arisen image of the two, the old man and woman brahmin. Across from this water on the rock is a self-arisen image of a gold fish, a turquoise fish and a poisonous snake in a lake of milk. Going on from here, Guru Rinpoché welcomed him and said, "Son, I will make your thirst water," and creating a furrow in the rock with his staff, he made manifest the attainment water of Chöjé Shelgompa, who accepted it. Saying that the water was like the performance of the feast offering on the 10th of the lunar month (tshe bcu), this place became know as "tséchu." This water has a good scent.

Up from here, inside the shrine room, there is a handprint of the great siddha Paksam Yeshé (dpag bsam ye shes) and a handprint of Shang Nabchipa (shang snab mchis pa) in the rock. There is a self-arisen image of the body-imprint of the great siddha Upa Chökyong ( $d b u$ pa chos skyong) and a self-arisen image of the five families of the mighty long life Khandromas. There are self-arisen images of the footprints of the great elephant Kala Rapten ( $k a$ la rab brtan) and of the excellent horse Bhalaha (bha la ha). And, one will encounter the footprint of Tsangnyon Heruka inside the shrine. Concealed from 
view on the flagstaff rock the eye of a lion can be seen. There is a footprint of the great siddha Kargyü Gön (dkar rgyud mgon). Inside, opposite that is a footprint of Drenyak ('dren yag), a footprint of Guru Rinpoch' and a footprint of Sangdor (sangs rdor), and footprints of Khandroma Yeshé Tsogyel and divine consort Mandāravā. There are the footprints of the five hundred previous births of the Bhagavan Buddha, and below those is a handprint of Khedrup Dorjé Wangpo (mkhas sgrub rdo rje dbang po), a footprint of the Nepalese woman Kala Siddhi. Above that is a footprint of the Nepalese woman Shākya dheva. Beyond these are a footprint of Kargyü Chölak (dkar rgyud chos lag), and footprints of eight-year-old khandromas. Onwards from those, there is a body imprint of the great siddha Tenzin Lhundrup (bstan 'dzin lhun grub) and his horse. Onward from these is a footprint of Grandmother Tsangpama (gtsang pa ma) and above it, the footprint of the great siddha Tenzin Gyeltsen (bstan 'dzin rgyal mtshan). To the side of this is a footprint of the great siddha Tenzin Lhundrup and one of Tamdrin. Onward from these is a footprint of the great Mongolian siddha. Above that is a footprint of the secret mantrin Tenzin Gyeltsen (gsang sngags bstan 'dzin rgyal mtshan), a footprint of Trulku Yeshé Ngödrup (sprul sku ye shes dngos grub) and above that a footprint of Jé Namkha Ludrup (rje nam mkha' klu grub) and a footprint of Dorjé Naljorma. Above that is a footprint of Rangrik Répa (rang rig ras pa). Up from here, there is a footprint of Khandro Kunzang Chödzom (kun bzang chos 'dzoms). To the side from here is a footprint of Damchö Gyeltsen (dam chos rgyal mtshan), a footprint of the Great Siddha Kagyü Zang (bka' brgyud bzang), and a footprint of the Great Siddha Tsaripa (rtsa ri pa). Below this is a footprint of Namkha Pelzang (nam $m k h a^{\prime}$ dpal bzang). It is explained like this up to the mighty temple.

From there, below the temple, is a self-arisen image of Pakmo's breast. In the area in front of that, in a lake of milk that is arisen from nectar in a precious bliss swirl, is a mass of flowers. On the rock on the other side from there, the Bhagavan Buddha cut through, up and down, tsen and dü demons. There is the footprint of an eight-year-old maiden, and the footprint of Trinle Gyeltsen ('phrin las rgyal mtshan). Across from that, is the Mother Khandromas' washing basin, and a self-arisen vulva (bha ga). Above that is Padampa Sangyé's hat. Up from there, on the rock is a self-arisen image of the bellows of Damchen Dorjé Lekpa. Above that, there is a self-arisen image of Guru Dorjé Drolö in the rock face.

The Five Great Caves: in the east is Drölma Cave, in the south is Pakmo Cave, in the west, Tamdrin Cave, where there is a face imprint of him, in the north is Garuda, and in the center, is a spacious, laid out cave. These are the five great caves.

First, when one goes in the circumambulation, in Pakmo cave is a self-arisen image of Pakmo's breast. Across from this is Guru Rinpoche's throne. Further on from here, are the footprints of the khandroma's dancing performances. Below this is a footprint of Khorlo Dompa. Here, in a cave with a corner building, Chöjé Shelgompa, having pretended to be sick, stayed there. He transformed into light, and this dissolved into the rock face. There is a self-arisen image of the Five Lineage Buddhas, pulling up and pressing down. On top of that, is a footprint of Zhabdül Ngawang Yulgyel (zhabs 'dul ngag dbang g.yul rgyal) and a precious bliss-swirl-shaped elixir of imortality collection place. Further beyond this, similar to the self-arisen image of the dice in the west, on the rock face there is a self-arisen image of a long-life vase, and Jetsun Milarepa, the hunter Gönpo Dorjé, the deer and the female dog Marchamma. In the east, is an image of Guru Rinpoché sitting in the midst of rays of sunlight. Above this, a golden key is hidden in the rock face. If one is a holy person, a further doorway to a né will be found from here.

In the south, there is the palace of the Lord of Death, in which there is a mirror of one's karma, and small black and white stones. On top of that, is a self-arisen image of Khandroma's blood ( $\mathrm{rag} \mathrm{ta}$ ). Below this, one day, Chöjé Shelgompa, hearing a man's voice in the Drölma Cave, went down to look. There, he saw the Twenty-One Drölmas dancing with Khorlo Dompa as their leader. Immediately, Khorlo Dompa went up and was hidden in the rock, the rock was blessed, and due to this, there is a self-arisen image of the secret part of his body. The twenty-one Drölmas dissolved into the rock, and so this place is well known as "Drölma Cave." Up from here, is the palace of the Lord, 
the Glorious Khorlo Dompa, and to the right of the Mother Dorjé Pakmo, is the Glorious Wisdom Protector with the raven face. To the left, in the middle of the open space are meditation caves.

The eastern snow mountain has the likeness of a proud lion. The southern mountain appears like a heaped-up mandala offering. The western mountain is like a fluttering black flag. The northern mountain is like an exalted person that touches the sky. To the right, the deity banner of the Buddhas of the Five Families descends. There is the deity Maheśvara, a Gönpo deity couple in sexual embrace, and a column of stone that is a pillar of heaven. There is a pillar of earth that is a short stone that has a self-arisen image of a prideful black serpent descending. There is the god of wealth in the appearance of a heart-rock. There is Pakpa Dönyö and a written picture of the eight auspicious symbols. There is a five-fold form of a pure banner and a secret Khandro cave, both a Denchok deity couple in sexual embrace and a Tamdrin/Pakmo deity couple in sexual embrace.

In the extensive and spacious cave in the center, there is a self-arisen image of Yeshe Gönpo's face and a letter "Āh."

On the rock face across the river, there is a self-arisen image of the palace of the nine-deity Hevajra and of a corpse being carried away by a tiger. On the rock face, there is an eleven-headed Öpagmé and a Chenrezik Khasarpani. Below these is a self-arisen image of a Tsen horse. Further on from that, is a self-arisen image of the Lords of the Three Families and onward from that is a self-arisen image of Chakna Dorjé. To the side of this is Sanyingpo (sa snying po) and on from there is Namkhai Nyingpo (nam mkha'i snying po).

This then is the explanation of the places of the great né, Saurata. It is a place for the accumulation of merit and the purification of defilements. Making worshipful prostrations to this place, it is said that it is special in that retreat there will protect one from suffering. It is the né where Chojé Rinpoché tread. It is the né where heroes and the sky-goers gather. It is the né where meditative experience and reflection will increase for those fortunate ones. It is distinctive, in that it clears away the sins of the sinful ones. It is distinctive in that it is the né that turns the minds of all sentient beings to the dharma. May all sentient beings in the six states of transmigration attain the state of bliss and attain the ultimate goal of liberation.

\section{References}

Anonymous. n.d. Gnas chen sau ra ța yis gnas yig bzhugs so. Transcribed by Lama Ngawang Negi.

Buffetrille, Katia. 1988. Pilgrimage in Tibet. Edited by Alex McKay. London and New York: Routledge, pp. 18-34. Buffetrille, Katia. 2007. The Great Pilgrimage of A myes rma chen: Written Tradition, Living Realities. In Mandala and Landscape. Edited by Alexander W. Macdonald. New Delhi: D. K. Printworld, pp. 75-132.

Buffetrille, Katia. 2013. "Pilgrimage in Tibet" in Oxford Bibliographies. Available online: http:/ / www.oxfordbibliographies.com/view / document/obo-9780195393521/obo-97801953935210122.xml?rskey=TpvM0P\&result=148 (accessed on 1 July 2017).

Coleman Graham, and Thupten Jinpa, eds. 2007. The Tibetan Book of the Dead: First Complete Translation, Penguin Classics Deluxe ed. Translated by Gyurme Dorje. New York: Penguin Classics.

Davidson, Ronald. 2003. Indian Esoteric Buddhism: A Social History of the Tantric Movement. New York: Columbia University Press.

Ekvall, Robert B., and James F. Downs. 1987. Tibetan Pilgrimage. Tokyo: Institute for the Study of Languages and Cultures of Asia and Africa.

Gray, David B. 2007. The Cakrasamvara Tantra (The Discourse of Śrī Heruka); Śrīherukābhidāna: A Study and Annotated Translation. New York: The American Institute of Buddhist Studies at Columbia University.

Huber, Toni. 2007. A Guide to La-Phyi Mandala: History, Landscape and Ritual in South-Western Tibet. In Mandala and Landscape. Edited by Alexander W. Macdonald. Delhi: D. K. Printworld, pp. 233-86. First published 1997.

Huber, Toni. 1999a. Sacred Spaces and Powerful Places in Tibetan Culture. Dharamsala: Library of Tibetan Works and Archives.

Huber, Toni. 1999b. The Cult of Pure Crystal Mountain: Popular Pilgrimage and Visionary Landscape in Southeast Tibet. New York and Oxford: Oxford University Press. 
Huber, Toni, and Tsepak Rigzin. 1999. A Tibetan Guide for the Pilgrimage to Ti-se (Mount Kailas) and mTsho Ma-pham (Lake Manasoravar). In Sacred Spaces and Powerful Places in Tibetan Culture. Edited by Toni Huber. Dharamsala: Library of Tibetan Works and Archives, pp. 125-53.

Kapstein, Matthew. 1998. A Pilgrimage of Rebirth Reborn: The 1992 Celebration of the Drigung Powa Chenmo. In Buddhism in Contemporary Tibet: Religious Revival and Cultural Identity. Edited by Melvyn Goldstein and Matthew Kapstein. Berkeley and Los Angeles: University of California Press, pp. 95-119.

Klimburg-Salter, Deborah. 1990. Tucci Himalayan Archives Report, 1: The 1989 Expedition to the Western Himalayas, and a Retrospective View of the 1933 Tucci Expedition. East and West 40: 145-71.

Klimburg-Salter, Deborah. 2002. The Nako Preservation Project. Available online: http://www.univie.ac.at/fspprogramm/wmf/ (accessed on 21 August 2017).

Lopez, Donald S. 1998. Prisoners of Shangri-La: Tibetan Buddhism and the West. Chicago: University of Chicago Press. McKay, Alex. 1998. Pilgrimage in Tibet. London and New York: Routledge.

Ramble, Charles. 2007a. Mandala and Landscape. Edited by Alexander W. Macdonald. Delhi: D. K. Printworld, First published 1997.

Ramble, Charles. 2007b. The Creation of the Bon Mountain of Kongpo. In Mandala and Landscape. Edited by Alexander W. Macdonald. Delhi: D. K. Printworld, pp. 133-232, First published 1997.

Thakur, Laxman. 1996. Nako Monastery: Archeological Notes from an Account of the Western Himalayan Expeditions. East and West 46: 337-52.

Tucci, Giuseppe. 1988. The Temples of Western Tibet and their Artistic Symbolism: the Monasteries of Spiti and Kunavar. Translated by Uma Marina Vesci. Edited by Lokesh Chandra. Indo-Tibetica, III. Satapitaka Series 349; New Delhi: Aditya Prakashan. First published 1937.

Tucci, Giuseppe. 1971. The Theory and Practice of the Mandala. New York: Samuel Weiser.

(C) 2017 by the author. Licensee MDPI, Basel, Switzerland. This article is an open access article distributed under the terms and conditions of the Creative Commons Attribution (CC BY) license (http:/ / creativecommons.org/licenses/by/4.0/). 